\title{
DEVELOPMENT OF TECHNOLOGIES FOR OBTAINING METAL POWDERS (IRON) FROM PRODUCTION WASTE AND STUDYING THEIR PROPERTIES
}

\author{
Mamarakhimov Khamza Mamadjanovich ${ }^{1}$, Sirojev Khayotjon Kholmurotovich ${ }^{1}$ \\ ${ }^{1}$ Academy of the Armed Forces of the Republic of Uzbekistan
}

Email: norxojaev.fayzulla.65@mail.ru

\begin{abstract}
The article discusses modern methods of obtaining iron powders, carried out their classification, analytical data of powders made from various types of raw materials. The kinetic regularities of the reduction of iron oxides are analyzed from the point of view of the adsorptionautocatalytic theory. The structure and mechanical properties of iron powders are considered. The morphology, structure, phase, and elementary composition of the mill scale of the Uzbek Metallurgical Plant are analyzed. Technology for the recovery of scale has been developed, including the following stages: drying at $250-340^{\circ} \mathrm{C}$, grinding in a ball mill for 2 hours, magnetic separation, sieving through a 40 mesh sieve, mixing the charge, recovery for 2 hours in $\mathrm{H}_{2}$ at a temperature: I - zone $-650-700^{\circ} \mathrm{C}$, II - zone $-950-1000^{\circ} \mathrm{C}$.
\end{abstract}

Keywords: Iron Powder, Kinetics, Regularity, Reduction, Oxide, Iron, Adsorption, Structure, Mechanical Properties.

\section{Introduction}

The most important task of the economic and social development of the Republic of Uzbekistan is the acceleration of scientific and technological progress in all branches of industrial production through the use of new materials, progressive technologies, and processes that ensure the predominant output of products with a decrease in material consumption per unit of consumer properties of machinery and equipment.

Powder metallurgy, which is one of the promising technologies of metallurgical and machine-building production, is of great importance in solving the problems posed, the methods of which make it possible not only to create materials with new quality and strength characteristics but also to introduce waste-free or low-waste technologies for the production of powder metal materials and products of various appointments based on them.

If in the manufacture of parts by traditional methods (casting, forging, stamping followed by mechanical processing) the metal utilization factor is 0.4-0.6, then powder metallurgy allows increasing it to $0.95-0.97$ [1].

Powder metallurgy processes, as a rule, proceed at temperatures lower than in large metallurgy (0.70.8 from the melting point), thereby providing energy savings. The energy consumption of powder metallurgy is $29 \mathrm{MJ} / \mathrm{kg}$ and is significantly lower than the energy consumption of foundry (34-38 MJ / $\mathrm{kg}$ ), cold stamping (41 MJ / kg), hot stamping (46-49 MJ / kg), cutting (66-82 MJ / kg) / kg) [2].

Powder metallurgy has one more advantage environmental because it is not associated with the release of harmful products that pollute the environment.

\section{The Relevance of the Problem}

At present, powder metallurgy is a rapidly developing industry, including the production of powders, metals, and alloys with particles of different dispersion, granules, threads, and other shapes; production of various machine parts and devices, tools, and special-purpose items; development and creation of metallic powder materials and non-metallic substrates; strengthening and restoration of machine parts and devices, as well as imparting increased mechanical or special physicochemical properties to the surface of products by methods of coating with powder composite materials [3].

Among the technological methods for the production of structural products, the method of cold pressing in closed molds with subsequent sintering has the greatest application [4].

The advantage of obtaining parts in this way is, first of all, high productivity and the possibility of their mass production without using or with the use of minor mechanical processing, which reduces waste and metal losses by 10-15 times in the 
manufacture of even products with complex shapes [5].

This technology retains inexhaustible possibilities for the creation of new materials based on iron powders with the additional use of alloying and heat treatment methods [6].

In recent years, hot pressing technology has been rapidly developing, which consists of the simultaneous pressing and sintering of powders, which makes it possible to obtain a dense product with a certain level of mechanical properties. With hot pressing, it is possible to significantly reduce the process temperature and thereby slow down the recrystallization processes, which ultimately leads to the formation of a fine-grained structure and an increase in mechanical properties in the lowtemperature region [7].

In contrast to conventional sintering, the methods of hot molding of blanks and products are carried out on more complex equipment, require special preparation of the tooling, and are inferior to it in performance. However, the effect in terms of strength properties and wear resistance is fully justified from both the technical and economic points of view. Methods of hot working with pressure are especially effective in the manufacture of large products, using difficult to sinter or substandard powders when it is necessary to obtain high density and strength of products, which are unattainable under the conditions of conventional sintering.

\section{Research Methods}

Metallographic, X-ray phase, electron microscopic analyzes, testing for mechanical properties.

\section{Research Results}

Methods for obtaining metal powder Methods for obtaining metal powder materials. To obtain iron powders, a wide variety of methods are used, which is explained not only by the need for powders for various purposes but also by the search for technologies that would ensure the production of cheap and high-quality powder [8].

Production of iron powders by the reduction method. A comparison of methods for the production of the iron powder allows us to conclude that the oxide reduction process is the most promising method for the production of cheap universalpurpose powder. Given the high productivity of the recovery process, the use of cheap raw materials and high-quality reductants, ensuring the completeness of recovery, correct engineering design, and full automation of technological cycles, it can be argued that the recovery process is the most profitable from a technical and economic point of view for obtaining cheap iron powders [9].

The existing methods for the reduction of iron oxides are classified according to the reductant used, the type of charge and the method of feeding it into the reduction zone, the pressure of the reducing gases, and the process temperature.

The reduction can be both an independent technological process for obtaining iron powders (the raw material is scale, ore), and the final part of the technological process in the production of powders by crushing steel melts with water or compressed air, in which iron particles are oxidized.

The process of reduction of iron oxides with hydrogen can be described by the following chemical reactions:

$$
\begin{gathered}
3 \mathrm{Fe}_{2} \mathrm{O}_{3}+\mathrm{H}_{2}=2 \mathrm{Fe}_{3} \mathrm{O}_{4}+\mathrm{H}_{2} \mathrm{O}+5,2 \mathrm{kcal} \\
\mathrm{Fe}_{3} \mathrm{O}_{4}+\mathrm{H}_{2}=3 \mathrm{FeO}+\mathrm{H}_{2} \mathrm{O}-15,2 \mathrm{kcal} \\
\mathrm{FeO}+\mathrm{H}_{2}=\mathrm{Fe}+\mathrm{H}_{2} \mathrm{O}-6,7 \mathrm{kcal} \\
\mathrm{Fe}_{3} \mathrm{O}_{4}+4 \mathrm{H}_{2}=3 \mathrm{Fe}+4 \mathrm{H}_{2} \mathrm{O}-43,4 \mathrm{kcal}
\end{gathered}
$$

General principles for the recovery of mill scale. One of the urgent problems of ferrous metallurgy is the use of secondary raw materials and production wastes in the national economy, which are not used in the smelting of high-quality metal in open-hearth and electric arc furnaces.

Such production wastes include scale, which is formed during the rolling of boiling carbon steels, containing $70-75 \%$ iron in the form of oxides. In the rolling shops of metallurgical plants, tens of thousands of tons of scale are accumulated, the chemical composition of which depends on the operation of the rolling technological process it was formed at. The purest scale is formed during the cooling of rolled products in cold spans: it is not clogged with difficult-to-recover oxides, does not require magnetic separation, and is a cheap and clean enough raw material source for obtaining iron powders.

For the reduction of scale with hydrogen, continuous muffle or tube furnaces with external heating are used. The dross is placed in trays or boats that move continuously through the hot zone of the oven. Hydrogen is supplied from the side of the refrigerator and the counter flow principle ensures the most complete recovery. The time required for complete-scale recovery depends on its type, particle size, layer thickness, temperature, pressure, and humidity of hydrogen, and other factors. According to one of the options [10], the reduction is carried out in a tubular two-zone furnace at $650-700{ }^{\circ} \mathrm{C}$ (I-zone) and $700-800^{\circ} \mathrm{C}$ (IIzone). 
Study of the morphology, structure, phase, and elemental composition of mill scale of the Uzbek metallurgical plant. Considering that steel at the plant is smelted from scrap metal, one should expect the presence of a wide range of impurity elements in various concentrations. Therefore, comparative studies of the morphology and chemical composition

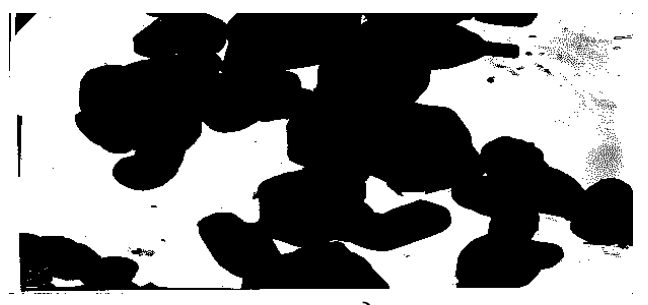

a) of mill scale and iron oxide grade pure for analysis (P.F.A.) were presented.

It has been shown that iron oxide particles have a generally spherical shape, which is typical for $\alpha$ $\mathrm{Fe}_{2} \mathrm{O}_{3}$ [11],[12]. The scale understudy is granules of various sizes (up to $10 \mathrm{~mm}$ ) of arbitrary shape with a porous structure (Fig. 1) [13].

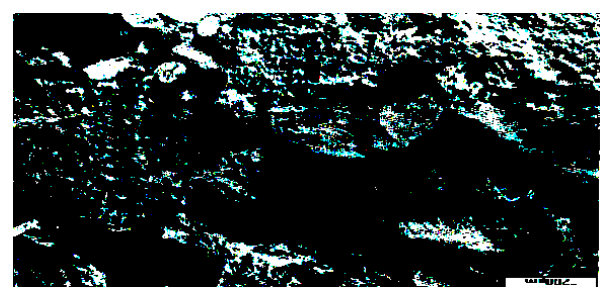

b)

Figure 1: Microstructure of the initial scale (a). x 150 and Electronic microstructure of milled scale (b). x 17.500

As can be seen from the X-ray diffraction pattern (Fig. 2), the scale contains wustite $(\mathrm{FeO})[0.248$; $\left.0.215 ; 0.151 ; 0.129 ; 0.123 \mathrm{~nm}^{3}\right]$, magnetite $\left(\mathrm{Fe}_{3} \mathrm{O}_{4}\right)$ [0.248; ; $\left.0.148 \mathrm{~nm}^{3}\right]$, and there are also traces of hematite $\left(\left(\alpha-\mathrm{Fe}_{2} \mathrm{O}_{3}\right)\left[0.252 ; 0.148 ; 0.110 \mathrm{~nm}^{3}\right]\right.$.

A comparison of the chemical composition of the scale of the Uzmetkombinat with the results of the analysis of the scale of the Orsk-Khalilovsk metallurgical plant (Table 1) indicates a significant difference in their chemical composition.
The scale of Uzmetkombinat is a powder of lowalloy steels.

Before the research, the scale was dried at 300 $400^{\circ} \mathrm{C}$, grinding in a ball mill at a ratio of the mass of raw materials and steel balls of 1: 1 for 1.3 and 6 hours.

The average chemical composition of the scale is given in the Table. 1.

Table 1. The average chemical composition of the scale of JPA "Uzmetkombinat" and Orsk-Khalilovskiy

\begin{tabular}{|c|c|c|c|c|c|c|c|c|c|c|c|c|}
\hline \multirow{2}{*}{ Elements } & \multirow{2}{*}{$\begin{array}{l}\mathrm{Fe} \\
\text { total }\end{array}$} & \multirow{2}{*}{$\mathrm{Si}$} & \multirow{2}{*}{$\mathrm{Al}$} & \multicolumn{9}{|c|}{$x \cdot 10^{-3}$} \\
\hline & & & & $\mathrm{Ca}$ & $\mathrm{Mg}$ & $\mathrm{Ba}$ & $\mathrm{Sr}$ & $\mathrm{Mn}$ & $\mathrm{Ti}$ & $S$ & $\mathrm{Nb}$ & $\mathrm{Ga}$ \\
\hline $\begin{array}{c}\text { Scale of } \\
\text { Uzmetkombinat } \\
\text { content, wt } \%\end{array}$ & $\begin{array}{l}72,0- \\
75,0\end{array}$ & 1,5 & 1,0 & 80 & 60 & 20 & 70 & 300 & 10 & 80 & 4 & 0,4 \\
\hline \multirow[t]{2}{*}{ Elements } & \multicolumn{12}{|c|}{$x \cdot 10^{-3}$} \\
\hline & $\mathrm{Cr}$ & $\mathrm{Ag}$ & $\mathrm{Cu}$ & $\mathrm{Pb}$ & $\mathrm{Zb}$ & $\mathrm{Ni}$ & Co & Mo & Sn & $\mathrm{Ge}$ & $\mathrm{La}$ & $\mathrm{Zr}$ \\
\hline $\begin{array}{c}\text { Scale of } \\
\text { Uzmetkombinat } \\
\text { content, wt } \%\end{array}$ & 30 & 20 & 400 & 6 & 8 & 100 & 10 & 10 & 3 & 10 & 10 & 5 \\
\hline \multirow[t]{2}{*}{ Elements } & \multirow{2}{*}{$\begin{array}{l}\mathrm{Fe} \\
\text { total }\end{array}$} & \multirow[t]{2}{*}{$\mathrm{Si}$} & \multirow[t]{2}{*}{$\mathrm{Al}$} & \multicolumn{9}{|c|}{$x \cdot 10^{-3}$} \\
\hline & & & & $\mathrm{Ca}$ & $\mathrm{Mg}$ & $\mathrm{Ba}$ & $\mathrm{Sr}$ & $\mathrm{Mn}$ & $\mathrm{Ti}$ & S & $\mathrm{Nb}$ & $\mathrm{Ga}$ \\
\hline $\begin{array}{c}\text { Scale of Orsk- } \\
\text { Khalilovsky } \\
\text { Metallurgical } \\
\text { Combine. content } \\
\text { wt,\% }\end{array}$ & 96,01 & 0,85 & - & 20 & - & - & - & 67 & & 0,7 & - & 20 \\
\hline \multirow[t]{2}{*}{ Elements } & \multicolumn{12}{|c|}{$x \cdot 10^{-3}$} \\
\hline & $\mathrm{Cr}$ & $\mathrm{Ag}$ & $\mathrm{Cu}$ & $\mathrm{Pb}$ & $\mathrm{Zb}$ & $\mathrm{Ni}$ & Co & Mo & $\mathrm{Sn}$ & $\mathrm{Ge}$ & $\mathrm{La}$ & $\mathrm{Zr}$ \\
\hline $\begin{array}{l}\text { The scale of Orsk- } \\
\text { Khalilovsky } \\
\text { Metallurgical } \\
\text { Combine. content } \\
\text { wt,\% }\end{array}$ & 25 & - & - & - & - & 25 & - & - & - & - & - & - \\
\hline
\end{tabular}


The reduction was carried out in a stream of hydrogen in a single-zone industrial furnace at 600 , 700 , and $800^{\circ} \mathrm{C}$ for 1 hour.

The reduction of scale at $600^{\circ} \mathrm{C}$ leads to the formation of $\alpha-\mathrm{Fe}(\sim 40 \%), \mathrm{FeO}(\sim 38 \%),[0.248$; $0.153 \mathrm{~nm}^{3}$ ] $\mathrm{FeO}^{*}(\sim 11 \%), \mathrm{Fe}_{3} \mathrm{O}_{4}\left[0.297 ; 0.161 \mathrm{~nm}^{3}\right]$ $(\sim 11 \%)$. The total iron content in the samples is $~$ 80 wt\% (Fig. 2, a).
The reduction of scale at $700{ }^{\circ} \mathrm{C}$ forms the system $\alpha-\mathrm{Fe}(\sim 55 \%), \mathrm{Fe}_{2} \mathrm{O}_{3}\left[0.250 ; 0.116 \mathrm{~nm}^{3}\right], \mathrm{FeO}$ $\left[0.151 ; 0.123 \mathrm{~nm}^{3}\right](\sim 23 \%), \mathrm{FeO} *(\sim 15 \%), \mathrm{Fe}_{3} \mathrm{O}_{4}$ [0.161 nm3] ( 7\%). The total iron content in the samples is $\sim 87 \mathrm{wt} \%$. (Fig. 2 , b)

The reduction of scale at $800^{\circ} \mathrm{C}$ leads to the formation of the $\alpha-\mathrm{Fe}(\sim 70 \%), \mathrm{FeO}[0.151 ; 0.124$ $\mathrm{nm}^{3}$ ] $(\sim 30 \%), \mathrm{FeO}^{*}(\sim 30 \%)$. The total iron content in the samples is $\sim 94 \mathrm{wt} \%$ (Fig. 2, c).

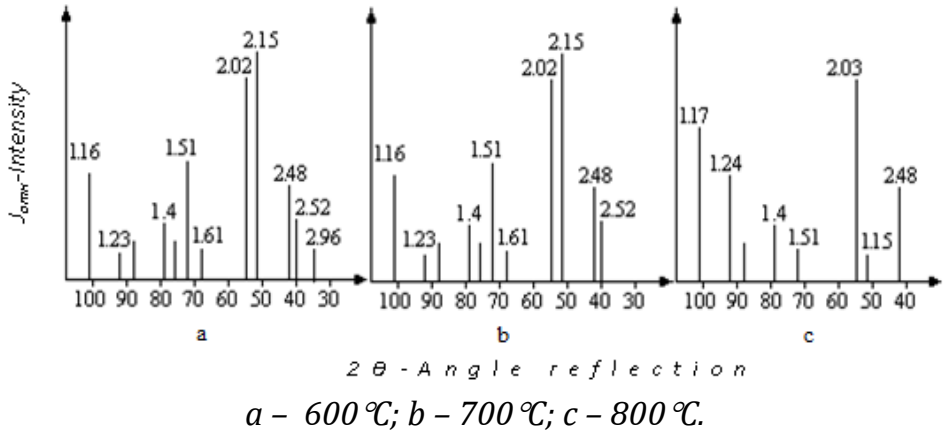

Figure 2: X-ray diffraction pattern of reduced iron powder at different temperatures.

The $\mathrm{FeO}^{*}$ phase present in all samples contains $48.5 \% \mathrm{Fe}$ and corresponds to the formula $\mathrm{Fe}_{0,35} \mathrm{O}$ and corresponds to the preparation obtained by the decomposition of $\mathrm{FeC}_{2} \mathrm{O}_{4}$ at $800{ }^{\circ} \mathrm{C}$ (ASTM, 6-0711) [14], [15].

$\mathrm{FeO}^{*}$ in terms of $\mathrm{d}(\mathrm{h \kappa} \ell$ ) values differs from $\mathrm{FeO}$ present in the initial scale and is, apparently, a solid solution FeO - Fe304 [0.368; 0.251; 0.220; 0.183; $0.163 ; 0.153 \mathrm{~nm}^{3}$ ] (based on FeO), which is usually written as $\mathrm{Fe}_{\mathrm{x}} \mathrm{O}(\mathrm{x}>0)$. To compare the results obtained, we also analyzed samples of iron oxide (P.F.A.) reduced at $800{ }^{\circ} \mathrm{C}$ (Fig. 3.a)

However, due to the high chemical activity of the obtained ultra granular iron powders, the presented diffractogram (Fig. 3.b) determines the phase composition of the already oxidized product. It includes a - Fe, $\mathrm{FeO}\left[0.248 ; 0.215 \mathrm{~nm}^{3}\right]$ and $\mathrm{Fe}_{3} \mathrm{O}_{4}$.

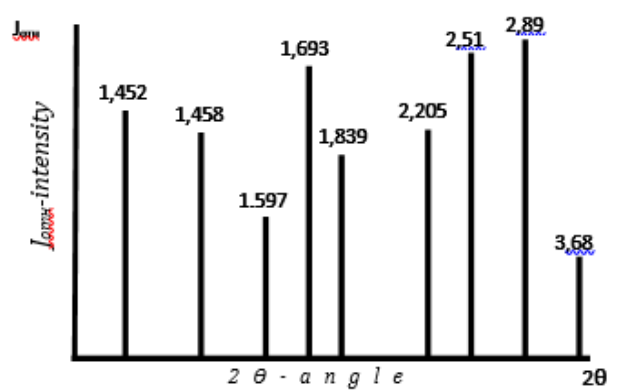

a)

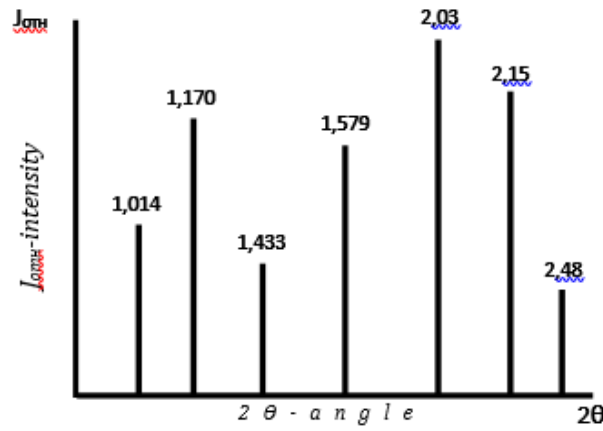

b)

Figure 3: X-ray diffraction pattern of initial iron oxide (a) and reduced iron at $800{ }^{\circ} \mathrm{C}(\mathrm{b})$ for 1 hour.

The spectral analysis of the samples obtained by reducing the scale at $700{ }^{\circ} \mathrm{C}$ is presented in Table 2 .

Under the accepted experimental conditions, the lower layers of the scale powder are not completely restored due to insufficient recovery time (600 and $700{ }^{\circ} \mathrm{C}$ ) or the difficulty of hydrogen penetration due to the formation of a dense surface crust by sintered iron particles (at $800^{\circ} \mathrm{C}$ ).
Based on the data obtained, it was concluded that the reduction process must be carried out in two stages at $600-700{ }^{\circ} \mathrm{C}$ and $800{ }^{\circ} \mathrm{C}$. It is necessary to add a baking powder to the scale composition - soot or iron powder.

Based on these prerequisites, a series of experiments were carried out to restore scale, ground in a ball mill for 1 hour, in a two-phase furnace at temperatures: I zone $-650{ }^{\circ} \mathrm{C}$; II zone $800^{\circ} \mathrm{C}$. 
Table 2. Average chemical composition (wt\%) of the iron powder obtained by reduction of scale at $700{ }^{\circ} \mathrm{C}$

\begin{tabular}{|c|c|c|c|c|c|c|c|c|}
\hline Element & $\mathrm{Si}$ & $\mathrm{Al}$ & $\mathrm{Ca}$ & $\mathrm{Mg}$ & $\mathrm{Ba}$ & $\mathrm{Sr}$ & $\mathrm{Mn}$ & $\mathrm{Ti}$ \\
\hline Masses \% & 2,0 & 2,0 & 0,06 & 0,2 & 0,02 & 0,02 & 0,50 & 0,03 \\
\hline Element & $\mathrm{Zb}$ & $\mathrm{Ni}$ & $\mathrm{Co}$ & $\mathrm{Mo}$ & $\mathrm{Sn}$ & $\mathrm{Nb}$ & $\mathrm{La}$ & $\mathrm{Zr}$ \\
\hline Masses \% & 0,008 & 0,20 & 0,01 & 0,01 & 0,003 & 0,007 & 0,007 & 0,004 \\
\hline
\end{tabular}

For the study, steel and graphite boats were used, and the scale powder was mixed with $5 \%$ graphite or $5-10 \%$ iron powder. The charge was poured both into clean boats and onto a thin layer of iron powder. The results obtained allowed us to conclude that under the selected reduction conditions, soot practically does not contribute to the reduction process and remains in the charge in a free state.

The best option is to recover the charge, which consists of a mixture of scale (90\%) and iron (10\%) powders. However, the iron powder sticks to the steel boat. Therefore, in terms of technology, preference should be given to graphite boats.

The results of X-ray phase analysis of the product obtained by reducing a mixture of scale (90\%) and iron $(10 \%)$ in graphite boats in two stages (1 hour $650{ }^{\circ} \mathrm{C}, 1$ hour $-800{ }^{\circ} \mathrm{C}$ ) showed that the resulting powder is $98 \%$ from $\alpha$-Fe $[0.253 ; 0.248 ; 0.215 ; 0.129$ $\mathrm{nm}^{3}$ ], (Fig. 4).

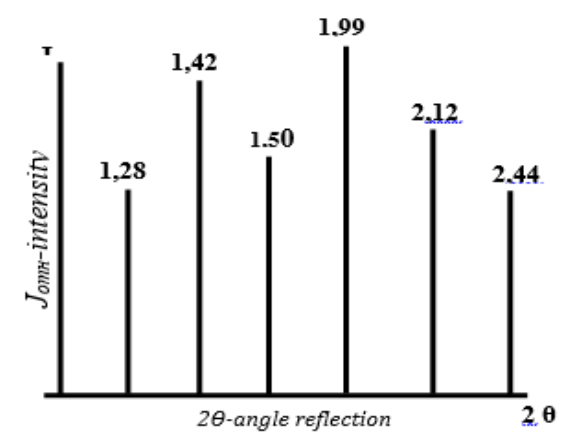

Figure 4. X-ray diffraction pattern of iron samples obtained by reducing scale in two stages: $1-650{ }^{\circ} \mathrm{C}(1 \mathrm{~h}), 2-1000{ }^{\circ} \mathrm{C}(1 \mathrm{~h})$

However, during storage, there is the slow oxidation of iron powder, [0.244; 0.212; 0.150; $0.128 ; \mathrm{nm}^{3}$ ], therefore, experiments proved the need to increase the temperature of the II stage of reduction to $950-1000{ }^{\circ} \mathrm{C}$ (Fig. 5).

Technological scheme of obtaining iron powders by reducing scale. Preparation of raw materials.

If the scale is taken from perennial dumps located in an open area, then it is preliminarily subjected to screening and flotation with running water to remove pieces of silica and alumina. The scale in the spans of rolling mills is not subjected to such an operation.
The scale is dried at $250-340{ }^{\circ} \mathrm{C}$ to remove moisture, oil, etc. Milling of scale is carried out in a ball mill at a ratio of the mass of raw materials and steel balls 1: 1 for 2 hours.

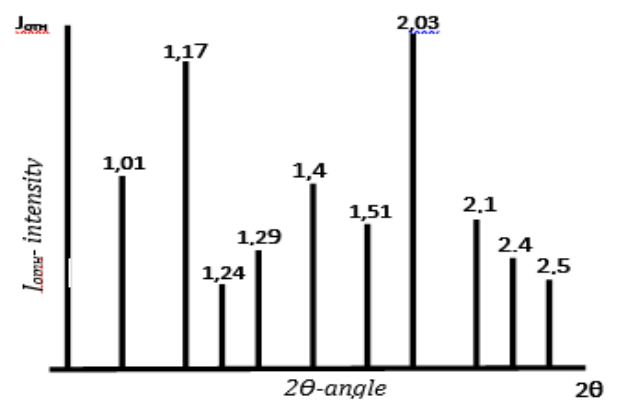

Figure 5: X-ray diffraction pattern of iron sampes obtained by reducing scale in two stages: $1-650{ }^{\circ} \mathrm{C}$ (1 hour), $2-800{ }^{\circ} \mathrm{C}$ (1 hour)

After grinding, the powder is magnetically separated on a belt conveyor equipped with an electromagnetic system to remove particles of impurities. The yield of the non-magnetic fraction is $3-10 \%$, depending on the scale contamination.

The powders are sieved through a 40 mesh sieve to remove coarse fractions, which are re-sent for grinding. The amount of the coarse fraction usually does not exceed 3-5\%.

Batch preparation. To accelerate the reduction process and facilitate the circulation of hydrogen, 8$10 \mathrm{wt} \%$ iron powder is added to the scale powder. The batch is mixed in a mixer or ball mill for 1 hour.

Scale recovery. The charge is poured into standard graphite boats with a layer thickness of 25$30 \mathrm{~mm}$, which are placed in the muffles of an industrial furnace, consisting of two zones, and a refrigerator, and are continuously advanced using a pusher.

The temperature of zone I of the furnace is 650 $700{ }^{\circ} \mathrm{C}$, zone II is $950-1000{ }^{\circ} \mathrm{C}$. Hydrogen is supplied from the side of the refrigerator and the counter flow principle ensures the most complete recovery. The residence time of boats with a charge in each temperature zone is 1 hour, i.e. the restoration process is carried out in 2 hours.

Grinding of the sponge iron. The resulting iron sponge (Fig. 6) is subjected to grinding in a ball mill for 2 hours. 


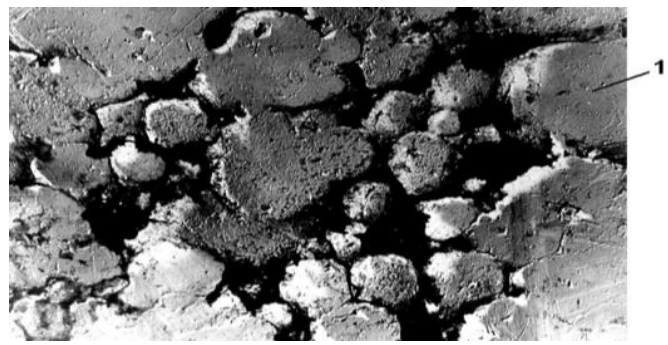

Figure 6: The microstructure of an iron sponge was obtained by reducing the mill scale x1000.

After grinding, the powder is sieved through a 60 mesh sieve. Coarse fractions of the powder are returned to the initial cycle for batching the scale.
Composition and properties of iron powders. The iron powder obtained by this technology is $\alpha$-Fe and has the chemical composition shown in table 3.

Table 3. Iron powder chemical composition

\begin{tabular}{|c|c|c|c|c|c|c|c|c|}
\hline Element & $\mathrm{Fe}$ & $\mathrm{Si}$ & $\mathrm{Al}$ & $\mathrm{Mg}$ & $\mathrm{Mn}$ & $\mathrm{Ba}$ & $\mathrm{Ti}$ & $\mathrm{Cr}$ \\
\hline Content\% mass & 98,9 & 0,3 & 0,1 & 0,01 & 0,2 & 0,009 & 0,001 & 0,05 \\
\hline Element & $\mathrm{Zr}$ & $\mathrm{S}$ & $\mathrm{C}$ & $\mathrm{O} 2$ & $\mathrm{Ca}$ & $\mathrm{Ni}$ & $\mathrm{Co}$ & other \\
\hline Content\% mass & 0,001 & 0,03 & 0,05 & 0,2 & 0,008 & 0,1 & 0,04 & 0,15 \\
\hline
\end{tabular}

\section{Conclusion}

The modern methods of obtaining iron powders are considered, their classification is carried out, analytical data of powders made from various types of raw materials are given. The kinetic regularities of the reduction of iron oxides are analyzed from the point of view of the adsorption-autocatalytic theory. The principles of reduction of mill scale with hydrogen are generalized, the influence of external factors on the reduction process is considered.

The structure and mechanical properties of iron powders are considered. It was concluded that, regardless of the production method and raw materials, iron powders have different properties with the same chemical composition.

The morphology, structure, phase, and elementary compositions of the mill scale of the Uzbek Metallurgical Combine are analyzed. It is concluded that it is a powder of low alloy steels.

The dependence of the change in the phase composition of iron on the temperature and time of scale reduction is investigated. As a result, an optimal mode of obtaining iron powder was developed, the characteristics of which meet the requirements of GOST 9849-86.

The scale recovery technology has been developed, which includes the following stages: drying at $250-340{ }^{\circ} \mathrm{C}$, grinding in a ball mill for 2 hours, magnetic separation, sieving through a 40 mesh sieve, mixing the charge, recovery for 2 hours in $\mathrm{H}_{2}$ at a temperature:

1.I - zone - $650-700^{\circ} \mathrm{C}$, II - zone - $950-1000^{\circ} \mathrm{C}$.

\section{References}

[1] Denisenko E.T., Kulik O. P., Yeremina T.V. Dispersnie kristallicheskie poroshki. Analiz nauchno - texnicheskoy literature [Dispersed crystalline powders. Analysis of scientific and technical literature]. // Poroshkovaya metallurgiya . - 1983. - № 4. - S. 4 - 12.

[2] Ayzenkolb F. Uspexi poroshkovoy metallurgii [Advances in powder metallurgy]. - $\mathrm{M}$ : Metallurgiya, $1989-570 \mathrm{~s}$.

[3] Antsiferov V.N., Akimenko V.V. Spechennie legirovannie stali [Sintered alloy steels]. - M.: Metallurgiya, 1988. - 88 s.

[4] Yermakov S.S. Vyaznikov N.F. Poroshkovie stali i izdeliya [Powder steels and products].-L.: Mashinostroenie, 1990. - 315 s.

[5] Polyak A.M., Sivaeva E.K. Sravnitelnaya ekonomicheskaya otsenka razlichnyx metodov polucheniya jeleznyx poroshkov [Comparative economic assessment of various methods for producing iron powders]. // Izvestiya VUZov. Chernaya metallurgiya. - M., 1986 - №7 - S 142 145.

[6] Karabasov Y.S. Fiziko - kimyo voststanovleniya jeleza iz oksidov [chemistry of reduction of iron from oxides]. M: Metallurgiya, 1986 - 199 s.

[7] Skoroxod V.V., Solonin Yu.M. Uvarova I.V. Kineticheskie, diffuzionnye i reologicheskie protsessy $\mathrm{v}$ texnologii poroshkovyh materiali [Kinetic, diffusion and rheological processes in powder technology]. - Kiyev: Naukova dumka. 1990 yil - S. 248. 
[8] Poroshkovaya metallurgiya v SSSR: Istoriya, sovremennoe sostoyanie, perspektyvi [Powder metallurgy in the USSR: history, current state, prospects]. / Pod red. I.N. Frantsevicha, V.I. Trefilova. - M: Nuka, 1986. - 296 s.

[9] Adrievskiy R.A. Poroshkovoe materialovedenie [Powder materials science]. - M: Nauka, 1991. $207 \mathrm{~s}$.

[10] Gretchenko V. Chumakov A.F., Roslavtsev N.A. Svoystva jeleznix i nizkolegirovannix poroshkov proizvodstva Sulinskogo metallurgicheskogo zavoda [Properties of iron and low-alloy powders produced by the Sulinskiy metallurgical plant]. // Poroshkovaya metallurgiya. - 1992. - №2 - S. 101 - 106.

[11] Jidomirov G.M., Pelmenshikov A.G., Janpeisov N.K., Grebenyuk A.G. Klasternыy podxod v kvantovogo - ximicheskix raschetax xemosorbtsii i geterogenno - kataliticheskix system [Cluster approach in quantum chemical calculations of chemisorption and heterogeneous - catalytic systems]. /Kinetika i kataliz. - 1987. - T.28 - №1. - S. 86 -99.

[12] Mamaraximov XM., Shakirov Sh.M. Razrabotka texnologii proizvodstva jeleznogo poroshka iz okalini [Development of technology for the production of iron powder from scale]. Jur. Kompozitsionnie materiali. 2007-№2- S.55-58
[13] Kalamazov.R.U., Mamaraximov.X.M., Shakirov Sh.M., Turaev.F.R. Rol razmerov chastits $v$ pressovanie poroshkovix materialov [The Role of Particle Sizes in Compaction of Powder Materials]. Jur. Vestnik. TashGTU2004.-№ 3 S.94-97.

[14] Mamaraximov X.M. Ustanovka goryachego pressovaniya poroshkovix materialov [Installation for hot pressing of powder materials]. Jur. Vestnik. TashGTU 2007-№4. S. 56-59.

[15] Mamaraximov.X.M. Poluchenie iznosostoykix pokritiy na osnove karbida volframa [Obtaining wear-resistant coatings based on tungsten carbide]// Jurnal Texnika i texnologiya. Moskva, 2007- №5. - S.66-69.

[16] X.M.Mamaraximov, A.K.Djuraev.

Antifriktsionnыe materiali i pokritiya na osnove poroshkov jeleza [Anti-friction materials and coatings based on iron powders]. Jur. Vestnik. TashGTU 2009-№2. S. 66-69.

[17] Norkudjayev F.R.AlikulovA.Kh. Abdurakhmonov Kh.Z.TursunovT.Kh. Examination of Thermophysical Processes in the Creation of Metal Layered Compositions. International Journal of Recent Technology and Engineering (IJRTE) ISSN: 2277-3878, Volume-8 Issue-2S10, September 2019. P 361-366. 